\title{
Chemical components, antioxidant potential and hepatoprotective effects of Artemisia campestris essential oil against deltamethrin-induced genotoxicity and oxidative damage in rats
}

\author{
Mongi Saoudi ${ }^{1}$, Marwa Ncir ${ }^{1}$, Manel Ben $\mathrm{Ali}^{2}$, Malek Grati ${ }^{3}$, Kamel Jamoussi ${ }^{3}$, Noureddine \\ Allouche $^{2}$ and Abdelfattah El Feki ${ }^{1}$ \\ ${ }^{1}$ Laboratory of Animal Ecophysiology, Sciences Faculty, University of Sfax, Sfax, Tunisia \\ ${ }^{2}$ Laboratory of Chemistry of Natural Products, Sciences Faculty, University of Sfax, Sfax, Tunisia \\ ${ }^{3}$ Laboratory of Biochemistry, CHU Hedi Chaker of Sfax, Tunisia
}

\begin{abstract}
In the present study, we evaluated the antioxidant potential of Artemisia campestris essential oil (ACEO) and the possible protective effects against deltamethrin induced hepatic toxic effects. The ACEO showed radical scavenging activity with IC50 $=47.66 \pm 2.51 \mu \mathrm{g} / \mathrm{ml}$, ferric reducing antioxidant power (FRAP) potential $($ EC50 $=5.36 \pm 0.77 \mu \mathrm{g} / \mathrm{ml})$, superoxide scavenging activity $($ IC50 $=0.175$ $\pm 0.007 \mu \mathrm{g} / \mathrm{ml}$ ) and ${ }^{\circ} \mathrm{OH}$ scavenging activity (IC50 $=0.034 \pm 0.007 \mu \mathrm{g} / \mathrm{ml}$ ). The obtained results of phenolic profile demonstrated that phenolic compounds are the major contributor to the antioxidant activity of ACEO. GC-MS analysis revealed the presence of 61 components in which monoterpene hydrocarbons constitute the major fraction (38.85\%). In in vivo study, deltamethrin exposure caused an increase of serum AST, ALT and ALP activities, hepatic malondialdehyde (MDA) (measured as TBARS) and conjugated dienes markers of lipid peroxidation (LPO), while antioxidant enzyme activities (SOD, CAT and GPx) decreased significantly. Furthermore, it induces DNA damage as indicated by DNA fragmentation accompanied with severe histological changes in the liver tissues. The treatment with vitamin $\mathrm{E}$ or ACEO significantly improved the hepatic toxicity induced by deltamethrin. It can be concluded that vitamin $\mathrm{E}$ and ACEO are able to improve the hepatic oxidative damage induced by deltamethrin. Therefore, ACEO is an important product in reducing the toxic effects of deltamethrin.
\end{abstract}

Key words: Deltamethrin - Oxidative damage - Artemisia campestris - Essential oil — Vitamin E

\section{Introduction}

Deltamethrin is a synthetic pyrethroid (type II), used as an insecticidal and anti-parasitic agent (Mazmanci et al. 2011). The advantages of their use are their photostability, high efficacy at low concentrations, easy disintegration, and low toxicity to birds and mammals (Rehman et al. 2006). However, pyrethroids have potential toxic effects on human health via inhalation, dermal contact and on the environment through contaminated food and water (Magendira Mani et al. 2014). Several studies have shown that pyrethroid caused alterations in hematology, biochemistry, reproduction, hepatic, renal, and nervous functions (Yousef et al. 2006; Saoudi et

Correspondence to: Mongi Saoudi, Department of Life Sciences, Sciences Faculty, BP 1171 Sfax 3000, Tunisia

E-mail: mongifss@yahoo.fr al. 2011). The main mechanism of deltamethrin as acaricidal and insecticidal effect is believed to result from its binding to a distinct receptor site on voltage-gated sodium channels and prolonging the open state by inhibiting channel deactivation and inactivation. However, deltamethrin could exert other effects on biological membranes at sites other than the voltage-dependent sodium channel because of its high hydrophobic profile. Reports showed that liver was found to accumulate a greater concentration of metabolites since it is the major site of deltamethrin metabolism (Abdel-Daim et al. 2013; Gündüz et al. 2015). However, deltamethrin was shown to induce oxidative damage in liver by enhancing the production of reactive oxygen species (ROS), including superoxide radicals $\left(\mathrm{O}_{2}{ }^{-}{ }^{-}\right)$, hydrogen peroxide $\left(\mathrm{H}_{2} \mathrm{O}_{2}\right)$ and hydroxyl radicals $(\mathrm{OH})$.

Naturally, the body has an established antioxidant mechanism to neutralise the produced ROS (Shivanoor and 


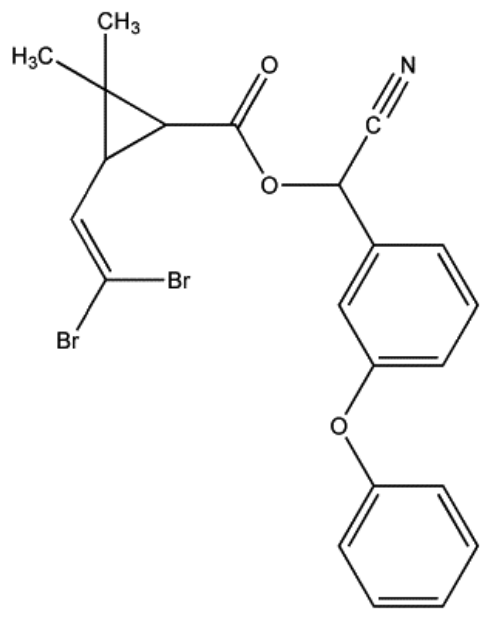

Figure 1. Chemical structure of deltamethrin.

David 2014). Neutralisation can be achieved by the enzymes including superoxide dismutase (SOD), catalase (CAT), glutathione reductase (GR) and glutathione peroxidase (GPx). ROS overproduction can directly attack and induce oxidative damage to proteins, lipids, mitochondria, lipoproteins, DNA, and change cell metabolism, accelerate aging, neurodegeneration and development of atherosclerosis, hypertension, type II diabetes as well as cancer (Nieradko-Iwanicka and Borzecki 2015). Though, in the extreme oxidative challenge, such as that observed in pesticide poisoning, the body's antioxidant machineries are overwhelmed. Vitamin $\mathrm{E}$ is considered as the most important lipid-soluble antioxidant that protects the brain against oxidative hazard (Galal et al. 2014). Vitamin E acts upon cell membranes and has the ability to neutralize compounds which may potentially disrupt membrane stability.

The use of natural antioxidants for curing pesticide induced toxicity is being studied extensively and with interest (Abd El-Rahman Refaie et al. 2014). Moreover, many plants used for medicine and food have been reported to be a rich source of antioxidants that inhibit or delay the oxidative degradation induced by ROS. The genus Artemisia, widespread over the world, growing wild over the Northern Hemisphere belongs to the Asteraceae family. A. campestris L., known in Tunisia as "dgouft" grows wild on the steppe and desert. In traditional medicine, $A$. campestris has been used as febrifuge and vermifuge against digestive troubles, gastric ulcer, and menstrual pain. The essential oil of $A$. campestris was more active than the extracts of many medicinal plants (Artemisia campestris L., Anthemis arvensis L., Haloxylon scoparium Pomel, Juniperus phoenicea L., Arbutus unedo L., Cytisus monspessulanus L., Thymus algeriensis and Zizyphus lotus L.) for scavenging peroxyl radicals and for inhibiting lipoxygenase (Boulanouar et al. 2013). Nevertheless, very few reports have investigated the hepatoprotective role induced by the essential oil of this medicinal plant $A$. campestris under oxidative stress situations. Therefore, the present study was aimed to investigate the protective effect of essential oil obtained from $A$. campestris on hepatic biomarkers of oxidative damage induced by deltamethrin in adult male rats.

\section{Material and Methods}

\section{Chemicals}

Deltamethrin (a-cyano-3-phenoxybenzyl (1R, 3R)-3-(2,2dibromovinyl)-2,2 dimethyl cyclopropanecarboxylate; C22H19Br2NO3) is a synthetic pyrethroid insecticide (Figure 1). It is available and used in experimentation in Tunisia. The name "decamethrin" was originally proposed for this compound and was used in the literature, but it was rejected because of a conflict with a trade mark. All other chemical products used in this study were purchased from Sigma Chemicals (Aldrich Chemical Company).

\section{Plant material and extraction of essential oil}

The aerial parts (stem and leaves) of A. campestris were collected from kasserine region, Tunisia. $500 \mathrm{~g}$ of fresh samples were cut into small pieces and subjected to hydro distillation using Clevenger-type apparatus for $2 \mathrm{~h}$. The essential oil was dried over anhydrous sodium sulphate and the purified essential oil was stored at $4^{\circ} \mathrm{C}$ until further use.

\section{Determination of antioxidant activity}

\section{$D P P H$ radical scavenging activity}

$\mathrm{DPPH}^{\bullet}$ (2,2-diphenyl-1-picrylhydrazyl) radical scavenging activity of $A$. campestris aerial parts essential oil was determined in terms of hydrogen donating or radical scavenging ability, using the stable radical 1.1-diphenyl-2-picrylhydrazyl (DPPH), according to the method described by Kirby and Schmidt (1997). Briefly, $1 \mathrm{ml}$ of various concentrations $(0.06-1.0 \mathrm{mg} / \mathrm{ml})$ of the extracts in methanol was added to $1 \mathrm{ml}$ of DPPH radical solution in methanol $4 \%(\mathrm{w} / \mathrm{v})$.

The mixture was shaken vigorously and kept at room temperature in the dark for 30 minutes. The antiradical activity was expressed as IC50 $(\mu \mathrm{g} / \mathrm{ml})$. The absorbance of the samples and control solutions were measured at $517 \mathrm{~nm}$ against a blank containing methanol and DPPH and inhibition of free radical DPPH in percent (I\%) was calculated as follows:

$\mathrm{I} \%=100 \times\left(\mathrm{A}_{\text {control }}-\mathrm{A}_{\text {sample }}\right) / \mathrm{A}_{\text {control }}$

where $\mathrm{A}_{\text {control }}$ is the absorbance of the control reaction (containing all reagents except the test compound), $A_{\text {sample }}$ 
is the absorbance of the test compound. Ascorbic acid was used as a control.

\section{Reducing power}

The reducing power was determined according to the method of Oyaizu (1986). A. campestris essential oil (0.06-1.0 mg/ $\mathrm{ml}$ ) was mixed with $1 \mathrm{ml}$ of $200 \mathrm{mM}$ sodium phosphate buffer (pH 6.6) and $1 \mathrm{ml}$ of $1 \%$ potassium ferricyanide $\left[\mathrm{K}_{3} \mathrm{Fe}(\mathrm{CN})_{6}\right]$ and the mixture was incubated at $50^{\circ} \mathrm{C}$ for $20 \mathrm{~min}$. Then $1 \mathrm{ml}$ of $10 \%$ trichloroacetic acid was added, and the mixture was centrifuged at $650 \times g$ for $10 \mathrm{~min}$. The upper layer $(1.5$ $\mathrm{ml}$ ) was mixed with $1.5 \mathrm{ml}$ of deionized water and $0.1 \mathrm{ml}$ of $0.1 \%$ ferric chloride $\left(\mathrm{FeCl}_{3}\right)$. Finally, the absorbance was measured at $700 \mathrm{~nm}$ against a blank. Increased absorbance of the reaction mixture indicated the increased reducing power. EC50 value $(\mathrm{mg} / \mathrm{ml})$ is the effective concentration giving an absorbance of 0.5 for reducing power and was obtained from linear regression analysis. Ascorbic acid was used as standard.

\section{Scavenging of superoxide radical (NBT test)}

The scavenging activity towards the superoxide radical $\left(\mathrm{O}_{2}{ }^{\cdot-}\right)$ was measured according to the method of Yagi et al. (2002). The nitroblue tetrazolium (NBT) reacts with the superoxide anion to give the oxidized NBT (tetrazolyl) which becomes water insoluble and purple formazan. The reaction mixture consisted of $100 \mu$ l of samples, phosphate buffer $(1 \mathrm{M})$, riboflavin $(0.12 \mathrm{mM})$, EDTA $(0.1 \mathrm{M})$ and NBT $(1.5 \mathrm{mM})$. The absorbance was read at $580 \mathrm{~nm}$ after illumination under UV lamp for 10 min against blank. The blank contained all the components except NBT.

The percentage of inhibition was calculated using the following formula:

$\mathrm{IP} \%=[1-(\mathrm{OD}$ sample/OD 100\%) $] \times 100$

where IP is the inhibition percentage, OD sample is the absorbance of the test compound and OD 100\% is the absorbance of the control reaction. The tested compound concentration, which provided 50\% inhibition (IC50, expressed in $\mu \mathrm{g} / \mathrm{ml}$ ), was calculated from the graph plotted the inhibition percentage against the extract concentration.

\section{Hydroxyl radical ( $(\mathrm{OH})$ scavenging assay}

The hydroxyl radical scavenging activity was determined by the method of Chung et al. (1997). The incubation mixture in a total volume of $1 \mathrm{ml}$ contained $0.1 \mathrm{ml}$ of phosphate buffer, varying volumes of essential oil, $0.2 \mathrm{ml}$ of $500 \mu \mathrm{M}$ ferric chloride, $0.1 \mathrm{ml}$ of $1 \mathrm{mM}$ ascorbic acid, $0.1 \mathrm{ml}$ of $1 \mathrm{M} \mathrm{EDTA}$, $0.1 \mathrm{ml}$ of $10 \mathrm{mM} \mathrm{H}_{2} \mathrm{O}_{2}$ and $0.2 \mathrm{ml}$ of 2-deoxyribose.
The contents were mixed thoroughly and incubated at room temperature for $60 \mathrm{~min} .1 \mathrm{ml}$ of $1 \%$ thiobarbituric acid (TBA) $(1 \mathrm{~g}$ in $100 \mathrm{ml}$ of $0.05 \mathrm{~N} \mathrm{NaOH})$ and $1 \mathrm{ml}$ of $2.8 \%$ trichloroanisole (TCA) were then added. All the tubes were kept in a boiling water bath for $30 \mathrm{~min}$. After cooling, the absorbance was measured at $532 \mathrm{~nm}$ against the blank containing water instead of essential oil. The percentage scavenging potential was calculated by using the formula:

$\%$ scavenging of $\cdot \mathrm{OH}=\left[\left(\mathrm{A}_{\text {control }}-\mathrm{A}_{\text {sample }}\right) / \mathrm{A}_{\text {control }}\right] \times 100$

where $\mathrm{A}_{\text {control }}$ is the absorbance of the control reaction and $A_{\text {sample }}$ is the absorbance in the presence of the sample.

\section{Determination of the total polyphenols}

The total phenolic contents of the ACEO were measured using a modified colorimetric Folin-Ciocalteu method (Wolfe et al. 2003). The total phenolic content was expressed as $\mathrm{mg}$ of gallic acid equivalents (GAE) per gram of dry weight through the calibration curve of gallic acid. The sample was analyzed in three replicates.

\section{Total tannins content}

The total tannins content in the plant essential oil were determined according to the method of Broadhurst and Jones (1978). $50 \mu \mathrm{l}$ of the essential oil was added to $3 \mathrm{ml}$ vanillin/ methanol (4\%). After stirring, $1.5 \mathrm{ml}$ concentrated $\mathrm{HCl}$ was added. The absorbance was read at $500 \mathrm{~nm}$ after $15 \mathrm{~min}$. The total tannin contents were expressed as mg catechin equivalent (C)/g of essential oil.

\section{GC and GC-MS analysis}

The chemical analysis of A. campestris essential oil was carried out with a GC-MS HP model 5975B inert MSD (Agilent Technologies, J\&W Scientific Products, Palo Alto, CA, USA), outfitted with an Agilent Technologies capillary DB-5MS column ( $30 \mathrm{~m}$ length; $0.25 \mathrm{~mm}$ i.d.; $0.25 \mu \mathrm{m}$ film thickness), and coupled to a mass selective detector (MSD5975B, ionization voltage $70 \mathrm{eV}$; all Agilent, Santa Clara, CA). Helium was used as carrier gas at $1 \mathrm{ml} / \mathrm{min}$ flow rate.

The oven temperature program was as follows: $1 \mathrm{~min}$ at $100^{\circ} \mathrm{C}$ ramped from 100 to $260^{\circ} \mathrm{C}$ at $4^{\circ} \mathrm{C} \mathrm{min}^{-1}$ and $10 \mathrm{~min}$ at $260^{\circ} \mathrm{C}$. The chromatograph was equipped with a split/ splitless injector used in the split mode. The split ratio was 1:100. Identification of components was assigned by matching their mass spectra with Wiley and NIST library data, standards of the main components and comparing their Kovats Retention Indices (KRI) with reference libraries and from the literature (Gomez and Ledbetter 1994; Adams 1995, 2007; Ruther 2000; Zoghbi et al. 2002; Marongiu et al. 2006; 


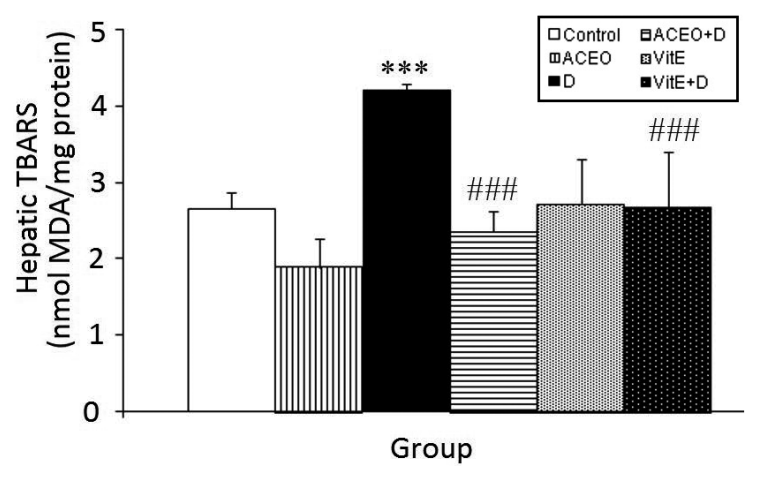

Figure 2. Effects of deltamethrin (D), Artemisia campestris essential oil (ACEO), vitamin $\mathrm{E}$ and their combination $(\mathrm{ACEO}+\mathrm{D}$ and $\mathrm{VitE}+\mathrm{D}$ ) on TBARS levels in liver of control (C) and experimental rats. Values are mean \pm SEM for six rats in each group. MDA, malondialdehyde; TBARS, thiobarbituric acid reactive substances; ${ }^{* * *} p<0.001 v$ s. control group; ${ }^{\# \#} p<0.001 v$ s. D group.

Morais 2009). The component concentration was obtained using semi-quantification by peak area integration from GC peaks and by applying the correction factors.

\section{Animals}

\section{Rats farming}

Male albino Wistar rats weighing 200-215 g were used for the experiment. The animals were purchased from the Central Pharmacy of Tunisia (SIPHAT, Tunisia). They were housed at $22 \pm 3^{\circ} \mathrm{C}$ with $12 \mathrm{~h}$ light/dark periods and minimum relative humidity of $40 \%$. The rats were fed with a commercial balanced diet (SICO, Sfax, Tunisia) and drinking water was offered ad libitum. All animal experiments were conducted according to the Ethical Committee Guidelines for the care and use of laboratory animals of our institution.

\section{Experimental protocols}

After 2 weeks of acclimatization, rats were randomly divided into six experimental groups of six animals each (Figure 2). The substances were administered in the morning (between 9:00 and 10:00 h) to non-fasted rats.

Group I (C): Control rats received distilled water, standard dry pellet diet ad libitum and corn oil intraperitoneally (i.p.) for two weeks.

Group II (ACEO): The rats were treated with A. campestris essential oil (i.p.) at the dose level of $200 \mathrm{mg} / \mathrm{kg}$ b.w. during two weeks of treatment (Radulovic et al. 2013).

Group III (D): Deltamethrin at the dose of $7.2 \mathrm{mg} / \mathrm{kg}$ b.w. (Catinot et al. 1989) in corn oil was applied to rats (i.p.) for two weeks.
Group IV (ACEO+D): Before deltamethrin (D) treatment, rats were pre-treated with $A$. campestris essential oil during two weeks of treatment and then deltamethrin was applied along with $A$. campestris essential oil for the second week.

Group V (Vit E): Vitamin E at the dose of $150 \mathrm{mg} / \mathrm{kg}$ b.w. (Seren et al. 2013) in olive oil was applied to rats (i.p.) during two weeks.

Group VI (VitE+D): Before deltamethrin (D) administration, rats were pre-treated with vitamin $\mathrm{E}$, at the dose of $150 \mathrm{mg} / \mathrm{kg}$ b.w. in olive oil, which was applied to rats (i.p.) during two weeks and then deltamethrin was applied along with vitamin $\mathrm{E}$ for the second week.

\section{Collection and preparation of tissue}

At the end of the treatments, the animals were killed on day 15 by decapitation. Blood samples were collected, allowed to clot at room temperature and serum separated by centrifuging at $2700 \times g$ for $15 \mathrm{~min}$ for various biochemical parameters. The liver was quickly excised, minced with ice cold saline, and blotted on filter paper. Homogenates were centrifuged at $10,000 \times g$ for $15 \mathrm{~min}$ at $4^{\circ} \mathrm{C}$ (Ultra Turrax T25, Germany) (1:2, w/v) in $50 \mathrm{mmol} / \mathrm{l}$ phosphate buffer ( $\mathrm{pH} 7.4)$. The supernatant and serum were frozen at $-30^{\circ} \mathrm{C}$ in aliquots until analysis. The protein content of the supernatant was determined using the method of Lowry et al. (1951).

\section{Hepatic serum markers}

Serum samples were obtained by the centrifugation of blood at $2700 \times g$ for $15 \mathrm{~min}$ at $4^{\circ} \mathrm{C}$, and were then divided into Eppendorf tubes. Isolated sera were stored at $-30^{\circ} \mathrm{C}$ until they were used for the determination of hepatic serum markers. The activities of serum alanine aminotransferase (ALT) (ALT/TGP A 03020), aspartate aminotransferase (AST) (AST/TGO A03010), and alkaline phosphatase (ALP) (ALP A03000) were measured using commercial reagents kits purchased from Elitrol and Biotrol (France).

\section{Oxidative stress analysis}

Thiobarbituric acid reactive substances (TBARS) measurements

Lipid peroxidation in the tissue homogenate was estimated by measuring TBARS and was expressed in terms of malondialdehyde (MDA) content which is the final product of lipid peroxidation, as described by Buege and Aust (1972). In short, $125 \mu \mathrm{l}$ of supernatants were homogenized by sonication with $50 \mu \mathrm{l}$ of TBS (Tris-buffered saline) and $125 \mu \mathrm{l}$ of TCA-BHT (butylated hydroxytoluene) in order to precipitate proteins and centrifuged $(1000 \times g, 10 \mathrm{~min}$, $\left.4^{\circ} \mathrm{C}\right) .200 \mu \mathrm{l}$ of obtained supernatant were mixed with $40 \mu \mathrm{l}$ of $\mathrm{HCl}(0.6 \mathrm{M})$ and $160 \mu \mathrm{l}$ of TBA dissolved in Tris and the 
mixture was heated at $80^{\circ} \mathrm{C}$ for $10 \mathrm{~min}$. The absorbance of the resultant supernatant was read at $530 \mathrm{~nm}$. The amount of TBARS was calculated by using an extinction coefficient of $156.105 \mathrm{mM}^{-1} \mathrm{~cm}^{-1}$ of MDA-TBA adduct.

\section{Determination of conjugated dienes}

The conjugated dienes in hepatic tissue were determined according to the method of Slater (1984). The hepatic tissues were homogenized separately in ice-cold phosphate buffer ( $\mathrm{pH} 7.4$ ) at a tissue concentration of $50 \mathrm{mg} / \mathrm{ml}$. The hepatic tissues were also homogenized in the same buffer at a concentration of $5 \mathrm{mg} / \mathrm{ml}$. A $0.5-\mathrm{ml}$ aliquot and a chloroformmethanol mixture $(2: 1)$ were taken in a centrifuge tube. This mixture was centrifuged at $1000 \times g$ for $5 \mathrm{~min}$. Chloroform was evaporated after steaming at $50^{\circ} \mathrm{C}$. The lipid residue was dissolved in $1.5 \mathrm{ml}$ methanol. Readings were taken at $233 \mathrm{~nm}$.

The levels of conjugated dienes were calculated using the following formula:

\section{Conjugated dienes $(\mathrm{nmol} / \mathrm{mg}$ proteins $)=\mathrm{OD} / \varepsilon \times 1 \times \mathrm{X}$}

where OD is optical density, $\varepsilon$ is the extinction coeffecient of conjugated dienes $\left(\varepsilon=2.7 \times 10^{4} \times 10^{-6} \mathrm{nM} / \mathrm{cm} / \mathrm{ml}\right)$, 1 is path of the cell and $\mathrm{X}$ is the concentration of proteins.

\section{Antioxidant enzyme studies}

In liver tissues, SOD activity was determined according to the colorimetric method of Beyer and Fridovich (1987) using the oxidizing reaction of nitroblue tetrazolium (NBT); CAT activity was measured by the UV colorimetric method of Aebi (1974) using $\mathrm{H}_{2} \mathrm{O}_{2}$ as substrate; glutathione peroxidase (GPx) activity was measured by a modification of the colorimetric method of Flohé and Günzler (1984) using $\mathrm{H}_{2} \mathrm{O}_{2}$ as substrate and the reduced GSH.

\section{Histopathological studies}

Pieces of liver tissues were excised, washed with normal saline and processed separately for histopathological observation. The liver and kidney tissues were fixed in bouin solution, dehydrated in graded (50-100\%) alcohol and embedded in paraffin. Thin sections $(4-5 \mu \mathrm{m})$ were cut and stained with routine hematox- ylin-eosin (H\&E). The sections were examined with optical microscope for histopathology changes, including cell necrosis, fatty change, and ballooning degeneration (Gabe 1968).

\section{Qualitative assay of DNA fragmentation by agarose gel electrophoresis}

The DNA was extracted from rat liver using Wizard Ge-180 nomic DNA Purification Kit (Quick-gDNA TM MiniPrep Catalog Nos. D3006, D3007, D3024, and D3025) (Zymo Research Corp, Irvine, 17062 Murphy Ave. Irvine, CA 92614, U.S.A.). DNA was then loaded onto agarose gel $(0.3 \mu \mathrm{g} /$ lane $)$. DNA laddering was determined by constant voltage mode electrophoresis (in a large submarine at $80 \mathrm{~V}$, for $60 \mathrm{~min}$ ) on a $1.7 \%$ agarose gel containing $0.5 \mu \mathrm{g} / \mathrm{ml}$ ethidium bromide (Miller et al. 1988). Gels were illuminated with $300 \mathrm{~nm} \mathrm{UV}$ light and a photographic record was made.

\section{Statistical analysis}

All values are expressed as mean \pm S.E.M. The results were analyzed by one-way analysis of variance (ANOVA) followed by Tukey test for multiple comparisons using SPSS for Windows (vers. 18). Differences were considered significant at $p<0.05$.

\section{Results}

Antioxidant capacities of A. campestris essential oil

The antioxidant capacities of $A$. campestris essential oil were studied with different assays such as: free radical scavenging (DPPH), reducing power (FRAP), scavenging of superoxide radical (NBT) and hydroxyl radical $\left({ }^{\circ} \mathrm{OH}\right)$ scavenging assays. The results are summarized in Table 1 . The essential oil exhibited a radical scavenging potential (IC50 $=47.66$ $\pm 2.51 \mu \mathrm{g} / \mathrm{ml})$ as compared to vitamin C (IC50 $=28.5 \pm$ $2.64 \mu \mathrm{g} / \mathrm{ml}$ ) which is used as positive control. The results of the reducing power test of ACEO revealed an EC50 $=5.36$ $\pm 0.77 \mu \mathrm{g} / \mathrm{ml}$ lower than the EC50 of vitamin C (EC50 = $0.117 \pm 0.002 \mu \mathrm{g} / \mathrm{ml}$ ) which is able to scavenge superoxide and peroxyls radicals. The reducing power of ACEO is important to reduce the $\mathrm{Fe}^{3+} /$ ferricyanide complex to the ferrous form.

Table 1. Scavenging capacity of A. campestris essential oil

\begin{tabular}{lccc}
\hline & $\begin{array}{c}\text { DPPH test } \\
(\mathrm{IC} 50 \mu \mathrm{g} / \mathrm{ml})\end{array}$ & $\begin{array}{c}\text { NBT test } \\
(\mathrm{IC} 50 \mu \mathrm{g} / \mathrm{ml})\end{array}$ & $\begin{array}{c}\text { FRAP test } \\
(\mathrm{EC} 50 \mu \mathrm{g} / \mathrm{ml})\end{array}$ \\
\hline A. campestris & $47.66 \pm 2.51$ & $0.175 \pm 0.007$ & $5.36 \pm 0.77$ \\
Vitamin C & $28.5 \pm 2.64$ & $0.117 \pm 0.002$ & $0.117 \pm 0.002$ \\
\hline
\end{tabular}

Values are mean \pm SEM of three replicates for each estimation; vitamin $\mathrm{C}$ was used as positive control. 
Table 2. Phytochemical composition of A. campestris essential oil

\begin{tabular}{|c|c|c|c|c|}
\hline $\mathrm{N}^{\circ}$ & $\mathrm{KI}^{\mathrm{a}}$ & Compound & $\begin{array}{c}\text { Composition } \\
(\%)\end{array}$ & $\mathrm{TR}^{\mathrm{b}}$ \\
\hline 1 & 935 & a-pinene & 5.92 & 8.35 \\
\hline 2 & 975 & $\beta$-pinene & 11.63 & 9.81 \\
\hline 3 & 992 & $\beta$-myrcene & 4.21 & 10.16 \\
\hline 4 & 1005 & a-phellandrene & 0.15 & 10.41 \\
\hline 5 & 1021 & a-terpinene & 0.67 & 10.77 \\
\hline 6 & 1029 & $\mathrm{R}(+)$ - limonen & 3.49 & 11.35 \\
\hline 7 & 1054 & Trans- $\alpha$-ocimene & 1.65 & 11.51 \\
\hline 8 & 1036 & Trans- $\beta$-ocimene & 3.10 & 11.88 \\
\hline 9 & 1059 & $\gamma$-terpinene & 5.54 & 12.24 \\
\hline 10 & 1162 & Cis- $\beta$ - terpineol & 0.24 & 12.35 \\
\hline 11 & 1092 & $\alpha$-terpinolene & 1.08 & 12.93 \\
\hline 12 & 1100 & Linalool L & 1.27 & 13.32 \\
\hline 13 & 1119 & (E)-4,8-Dimethyl-1,3,7,-nonatriene & 0.40 & 13.72 \\
\hline 14 & 1087 & $\begin{array}{l}\text { 2-cyclohexen-1-ol,1-methyl-4- } \\
\text { (1-methyl)-, trans }\end{array}$ & 0.61 & 13.92 \\
\hline 15 & 1132 & alloocimene & 1.30 & 14.13 \\
\hline 16 & 990 & Pentamethylcyclopentadiene & 1.37 & 14.43 \\
\hline 17 & 1162 & Pinocarvone & 0.15 & 15.04 \\
\hline 18 & 1165 & Pinocamphone & 0.54 & 15.37 \\
\hline 19 & 1183 & Terpinene-4-ol & 4.50 & 15.72 \\
\hline 20 & 1190 & Crypton & 0.28 & 15.84 \\
\hline 21 & 1197 & $a$-terpineol & 2.52 & 16.09 \\
\hline 22 & 1194 & Myrtenol & 0.37 & 16.18 \\
\hline 23 & 1223 & Trans-(+)-carveol & 0.15 & 16.76 \\
\hline 24 & 1236 & Cis-3-hexenyl isovalerate & 0.61 & 17.17 \\
\hline 25 & 1253 & Piperitone & 0.48 & 17.70 \\
\hline 26 & 1260 & Geraniol & 0.45 & 17.75 \\
\hline 27 & 1277 & Cinnamaldéhyde & 0.56 & 18.22 \\
\hline 28 & 1286 & Bornyl acetate & 0.17 & 18.50 \\
\hline 29 & 1307 & Carvacrol & 0.11 & 18.76 \\
\hline 30 & 1332 & 4-hydroxy-3-methylacetophenone & 0.26 & 19.22 \\
\hline 31 & 1322 & Z-3-hexenyl tiglate & 0.74 & 19.58 \\
\hline 32 & 1335 & Hexyl tiglate & 0.28 & 19.71 \\
\hline 33 & 1326 & Bicycloelemene & 0.37 & 19.87 \\
\hline 34 & 1342 & Eugenol & 0.10 & 20.49 \\
\hline 35 & 1366 & Neryl-acetate & 0.29 & 20.59 \\
\hline 36 & 947 & Camphene & 0.11 & 20.73 \\
\hline 37 & 1377 & a-Copaene & 0.12 & 20.89 \\
\hline 38 & 1354 & Geranyl acetate & 2.78 & 21.21 \\
\hline 39 & 1492 & Isoeugenyl methyl ether & 0.18 & 21.66 \\
\hline 40 & 1460 & $\alpha$-amorphene & 0.34 & 22.02 \\
\hline 41 & 1391 & $\beta$-cubebene & 0.20 & 22.26 \\
\hline 42 & 1453 & a-Caryophyllene & 0.25 & 22.87 \\
\hline 43 & 1480 & (+)-Epi-bicyclosesquiphellandrene & 0.10 & 23.11 \\
\hline 44 & 1485 & Germacrene -D & 1.75 & 23.61 \\
\hline 45 & 1470 & Bicyclogermacrene & 0.50 & 23.94 \\
\hline 46 & 1505 & $\alpha$ - muurolene & 0.17 & 24.01 \\
\hline 47 & 1510 & E,E- $\alpha$-farnesene & 0.26 & 24.19 \\
\hline 48 & 1514 & $\gamma$-cadinene & 0.25 & 24.36 \\
\hline 49 & 1523 & $\delta$-cadinene & 0.71 & 24.59 \\
\hline 50 & 1642 & Vulgarol B & 0.17 & 24.84 \\
\hline 51 & 1562 & Nerolidol & 0.72 & 25.61 \\
\hline 52 & 1596 & $(+)$ spathulenol & 2.70 & 26,04 \\
\hline 53 & 1305 & Azulene & 0.51 & 26.12 \\
\hline 54 & 1480 & $\gamma$-gurjunene & 0.60 & 26.30 \\
\hline 55 & 1475 & Geranyl propionate & 1.70 & 26.59 \\
\hline 56 & 1641 & Tau-cadinol & 1.44 & 27.40 \\
\hline 57 & 1651 & $\beta$-eudesmol & 6.54 & 27.84 \\
\hline 58 & 1745 & Mintsulfide & 0.31 & 29.47 \\
\hline 59 & 1960 & Hexadeconoic acid (palmitic acid) & 0.47 & 34.13 \\
\hline 60 & 2115 & Oleic acid & 0.24 & 37.41 \\
\hline \multirow[t]{7}{*}{61} & 2170 & stearic acid & 0.19 & 37.72 \\
\hline & & Identified components & $78.87 \%$ & \\
\hline & & Monoterpenes hydrocarbons & $38.85 \%$ & \\
\hline & & Oxygenated monoterpenes & $11.39 \%$ & \\
\hline & & Sesquiterpenes hydrocarbons & $5.62 \%$ & \\
\hline & & Oxygenated sesquiterpenes & $11.57 \%$ & \\
\hline & & Other compounds & $11.44 \%$ & \\
\hline
\end{tabular}

The antioxidant activity was also determined by the inhibition of the oxidation of NBT (by scavenging the superoxide anion $\left(\mathrm{O}_{2}{ }^{\cdot-}\right)$ ). The ACEO has shown lower superoxide anion scavenging activity $(\mathrm{IC} 50=0.175 \pm 0.007 \mu \mathrm{g} / \mathrm{ml})$ as compared to vitamin $\mathrm{C}(\mathrm{IC} 50=0.117 \pm 0.002 \mu \mathrm{g} / \mathrm{ml})$. ${ }^{\circ} \mathrm{OH}$ is a highly reactive free radical formed in biological systems. ACEO revealed that ${ }^{\circ} \mathrm{OH}$ assay is important $(\mathrm{IC} 50=0.034 \pm 0.007 \mu \mathrm{g} /$ $\mathrm{ml})$ as compared to vitamin C $(\mathrm{IC} 50=0.0155 \pm 0.002 \mu \mathrm{g} / \mathrm{ml})$.

\section{Polyphenolic contents of A. campestris essential oil}

Total phenolic content could be regarded as an important indication of antioxidant properties of plant extracts. The determination of total phenolic content of ACEO was measured by Folin Ciocalteau reagent in terms of gallic acid equivalents (GAEs). ACEO revealed important contents in polyphenols $(131.64 \pm 17.47 \mu \mathrm{g} \mathrm{GAE} / \mathrm{mg}$ extract $)$ and tannins (189.55 \pm $34.58 \mu$ g equivalent catechin/mg extract).

\section{Chemical composition of A. campestris essential oil}

Essential oil obtained from fresh leaves of $A$. campestris showed a yield of $0.16 \%$. Its chemical composition is presented with the retention indices in Table 2. The GC-MS analysis of the oil samples revealed the presence of a total of 61 components. The main compounds were $\beta$-pinene (11.63\%) and $\beta$-eudesmol (6.54\%) followed by $\alpha$-pinene $(5.92 \%), \gamma$-terpinene $(5.44 \%)$, terpinene4 -ol (4.5\%), $\beta$-myrcene (4.21\%), trans- $\beta$-ocimene $(3.1 \%)$ and a-terpineol (2.52\%). Monoterpene hydrocarbons constitute the major fraction of the oil (38.85\%) while sesquiterpene hydrocarbons accounted for 5.62\%. Oxygenated monoterpenes and oxygenated sesquiterpenes amounted to $11.39 \%$ and $11.57 \%$, respectively. This oil is relatively more concentrated on $\alpha$-pinene, $\beta$-eudesmol, terpinene-4-ol and $\alpha$-terpineol and less rich in $\beta$-pinene than that reported by Akrout et al. (2011).

\section{Serum hepatic biochemical parameters}

The changes in AST, ALT and ALP activities in adult male rats exposed to deltamethrin, A. campestris essential oil, vitamin $\mathrm{E}$ and their combination for two weeks are shown in Table 3. Activities of AST, ALT and ALP in deltamethrin-exposed rats significantly increased as compared to control group. The pre and co-administration of vitamin E or ACEO in deltamethrin rats reversed and alleviated considerably the activities of AST, ALT and ALP as compared to deltamethrin and control group. There were no significant changes in ACEO or vitamin E groups compared to control for AST, ALT and ALP.

\section{Oxidative stress analysis}

In this study, MDA and conjugated dienes (Figures 2 and 3) were used as markers of oxidative damage to liver in 
deltamethrin-exposed rats. Current findings showed that MDA and conjugated dienes levels were increased (37\% and $46 \%$, respectively) significantly in deltamethrin-exposed group compared to control. The pre and co-treatment with ACEO or vitamin E protected against the lipid peroxidation as confirmed by suppression of conjugated dienes and MDA levels induced by deltamethrin treatment. Vitamin E or ACEO alone had no effects on lipid peroxidation.

Results illustrated that deltamethrin exposure (2 weeks) induced a significant decrease in antioxidant responses (CAT, SOD and GPx) in liver (Table 4), while ACEO or vitamin E notably influenced and improved enzymatic activities involved in antioxidant responses.

\section{Histopathological findings}

Figure 4 shows the histology of untreated and treated groups of liver tissues. Normal liver histoarchitecture showed normal hepatocytes and sinusoidal architectures which were observed in the control, A. campestris essential oil and vitamin E groups, while deltamethrin-treated group illustrated severe liver damage including vacuolisation, inflammatory cell infiltration and vascular congestion. ACEO or vitamin E treatments clearly reduced the lesions caused by deltamethrin treatment.

\section{DNA fragmentation by agarose gel electrophoresis}

Figure 5 shows the qualitative changes in the integrity of the liver genomic DNA. No specific DNA fragments were observed in control, ACEO and vitamin E groups. However, the treatment with deltamethrin $(7.2 \mathrm{mg} / \mathrm{kg}$ b.w. $)$ induced a marked DNA fragmentation in liver tissue as compared to control group. The pre and co-administration of rats treated with deltamethrin and ACEO or vitamin E showed a significant restoration of DNA as compared to control and deltamethrin group alone.

Table 3. Effects of deltamethrin (D), A. campestris essential oil (ACEO), vitamin E (VitE) and their combination on biochemical parameters (AST, ALT and ALP) in adult male rats

\begin{tabular}{lccc}
\hline Group & AST (U/l) & ALT (U/l) & ALP (U/l) \\
\hline Control & $207.33 \pm 10.78$ & $55 \pm 0.77$ & $266 \pm 3.57$ \\
ACEO & $231.34 \pm 2.16$ & $53 \pm 5.07$ & $255.8 \pm 14.39$ \\
D & $313 \pm 12.37^{* *}$ & $70.5 \pm 4.11^{* *}$ & $422.5 \pm 3.47^{* * *}$ \\
ACEO+D & $255 \pm 15.89^{\#}$ & $52.6 \pm 4.41^{\# \#}$ & $276 \pm 6.88^{\star, \# \#}$ \\
VitE & $235 \pm 6.96$ & $50 \pm 2.52$ & $243.34 \pm 21.43$ \\
VitE+D & $231.25 \pm 20.1^{\#}$ & $51.2 \pm 5.81^{\# \#}$ & $289.67 \pm 24.48^{\star, \# \#}$ \\
\hline
\end{tabular}

Values are mean \pm SEM for six rats in each group. AST, aspartate aminotransferase; ALT, alanine aminotransferase; ALP, alkaline phosphatase. ${ }^{*} p<0.05,{ }^{* *} p<0.01,{ }^{* * *} p<0.001 v$ s. control group; ${ }^{\#} p<0.05,{ }^{\# \#} p<0.01$ vs. D group.

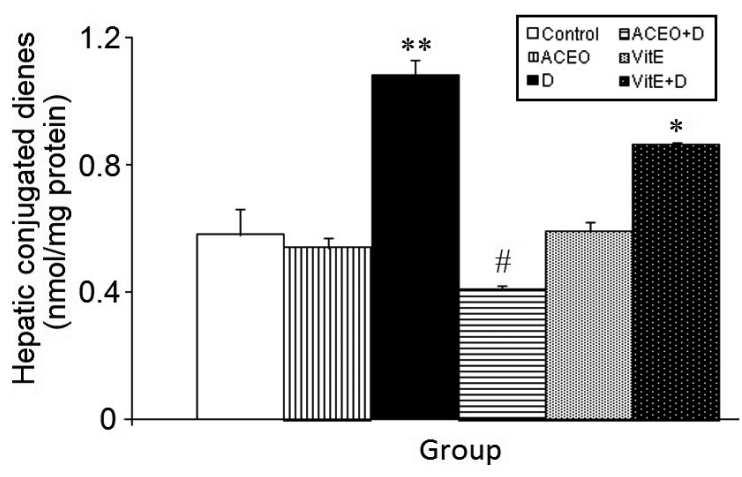

Figure 3. Effects of deltamethrin (D), Artemisia campestris essential oil (ACEO), vitamin E and their combination (ACEO+D and $\mathrm{VitE}+\mathrm{D}$ ) on conjugated dienes levels in liver of control (C) and experimental rats. Values are mean \pm SEM for six rats in each group. ${ }^{\star} p<0.05,{ }^{\star \star} p<0.01 v s$. control group; ${ }^{\#} p<0.05 v s$. D group.

\section{Discussion}

The antioxidant potential of ACEO investigated in the present study revealed significant prevention of deltamethrininduced hepatotoxicity and oxidative damage in male adult Wistar rats. The antioxidant activity of plants is mainly contributed by the active compounds of essential oil and phenolic fraction present in them. In order to achieve this purpose, the antioxidant activity and chemical composition of the ACEO were investigated. The data presented in this study demonstrated that ACEO had antioxidant and free radical scavenging activities. According to the results obtained, the $\mathrm{DPPH}^{\bullet}$ radical scavenging potential of ACEO was lower than that of the standard, vitamin $\mathrm{C}$. The results of the present paper are comparable with the previous study made by Radulovic et al. (2013) which reported the $\mathrm{DPPH}^{\circ}$ radical scavenging potential of Artemisia annua $\mathrm{L}$. The

Table 4. Effects of deltamethrin (D), A. campestris essential oil (ACEO), vitamin E (VitE) and their combination on activity of antioxidant enzymes (SOD, CAT and GPx) in adult male rats

\begin{tabular}{lccc}
\hline Group & $\begin{array}{c}\text { SOD } \\
(\mathrm{U} / \mathrm{mg} \text { protein })\end{array}$ & $\begin{array}{c}\mathrm{CAT} \\
\left(\mu \mathrm{mol} \mathrm{H}_{2} \mathrm{O}_{2} / \mathrm{mg}\right. \\
\text { protein })\end{array}$ & $\begin{array}{c}\mathrm{GPx} \\
(\mu \mathrm{mol} \mathrm{GSH} / \\
\text { min/mg protein })\end{array}$ \\
\hline Control & $11.07 \pm 1.36$ & $182.68 \pm 27.27$ & $0.11 \pm 0.01$ \\
ACEO & $8.03 \pm 1.24$ & $138.72 \pm 41.8$ & $0.07 \pm 0.02$ \\
D & $7.62 \pm 3.02^{*}$ & $110.6 \pm 48.16^{*}$ & $0.06 \pm 0.02^{* *}$ \\
ACEO+D & $8.65 \pm 0.25$ & $139.98 \pm 26.51$ & $0.07 \pm 0.007^{\#}$ \\
VitE & $8.64 \pm 2.5$ & $165.37 \pm 38.78$ & $0.1 \pm 0.009$ \\
VitE+D & $9.29 \pm 2.49^{\#}$ & $137.68 \pm 35.22$ & $0.13 \pm 0.04^{\# \#}$ \\
\hline
\end{tabular}

Values are mean \pm SEM for six rats in each group. SOD, superoxide dismutase); CAT, catalase; GPx, glutathione peroxidase. ${ }^{*} p<0.05$, ${ }^{* *} p<0.01,{ }^{* * *} p<0.001$ vs. control group; ${ }^{\#} p<0.05,{ }^{\# \# \#} p<0.001$ vs. D group. 
radical scavenging activity of essential oil can be attributed to the presence of its major phenolic compounds, particularly monoterpene hydrocarbons and their recognized impact on lipid oxidation (Coutinho de Oliveira et al. 2012).

The obtained results are in accordance with the findings of several studies which reported that the efficiency of an antioxidant component to reduce DPPH essentially depends on its hydrogen donating ability, which is directly related to the presence of polyphenolic compounds (Kasangana et al. 2015). The reducing power assay is often used to demonstrate the ability of natural antioxidant to donate an electron or hydrogen (Senthil Kumar et al. 2012).

As shown in our results, the reducing capacity of the essential oil from $A$. campestris remained lower than that of vitamin $C$. This difference may be explained by lower content of electron donor compounds in the chemical composition of this oil which was characterized by the abundance of monoterpene hydrocarbons. The $\mathrm{O}_{2}{ }^{\bullet-}$ scavenging activity of ACEO was compared with vitamin $\mathrm{C}$ used as standard. The result of the present study is in agreement with the previous study which revealed that antioxidant properties of some essential oil are effective via scavenging of $\mathrm{O}_{2}{ }^{-}$radical (Okoh et al. 2014). The monoterpenes constituted $50.24 \%$ and the sesquiterpenes $17.19 \%$, of which the monoterpene hydrocarbons had the most important contributions (38.85\%). $\alpha$-pinene, $\beta$-pinene, $\beta$-myrcene, $\mathrm{R}(+)$ - limonen, trans- $\beta$-ocimene, $\gamma$-terpinene, terpinene4-ol, a -terpineol, geranyl acetate, $(+)$ spathulenol and $\beta$-eudesmol are the major compounds in ACEO. ACEO is rich in polyphenols and has significant antioxidant activity in vitro. In addition, this antioxidant capacity is eventually related to a richness of monoterpenes which are aromatic plant essences. The in vitro antioxidant activity of each compound of ACEO has not been studied in this work. ACEO has a high antioxidant activity evaluated by the in vitro and in vivo tests. This antioxidant activity concerns all ACEO compounds that act together to neutralize free radicals and reduce oxidative damage.

The essential oil showed lower scavenging potential of ${ }^{\bullet} \mathrm{OH}$. The ability of essential oils to reduce ${ }^{\circ} \mathrm{OH}$ seems to be directly

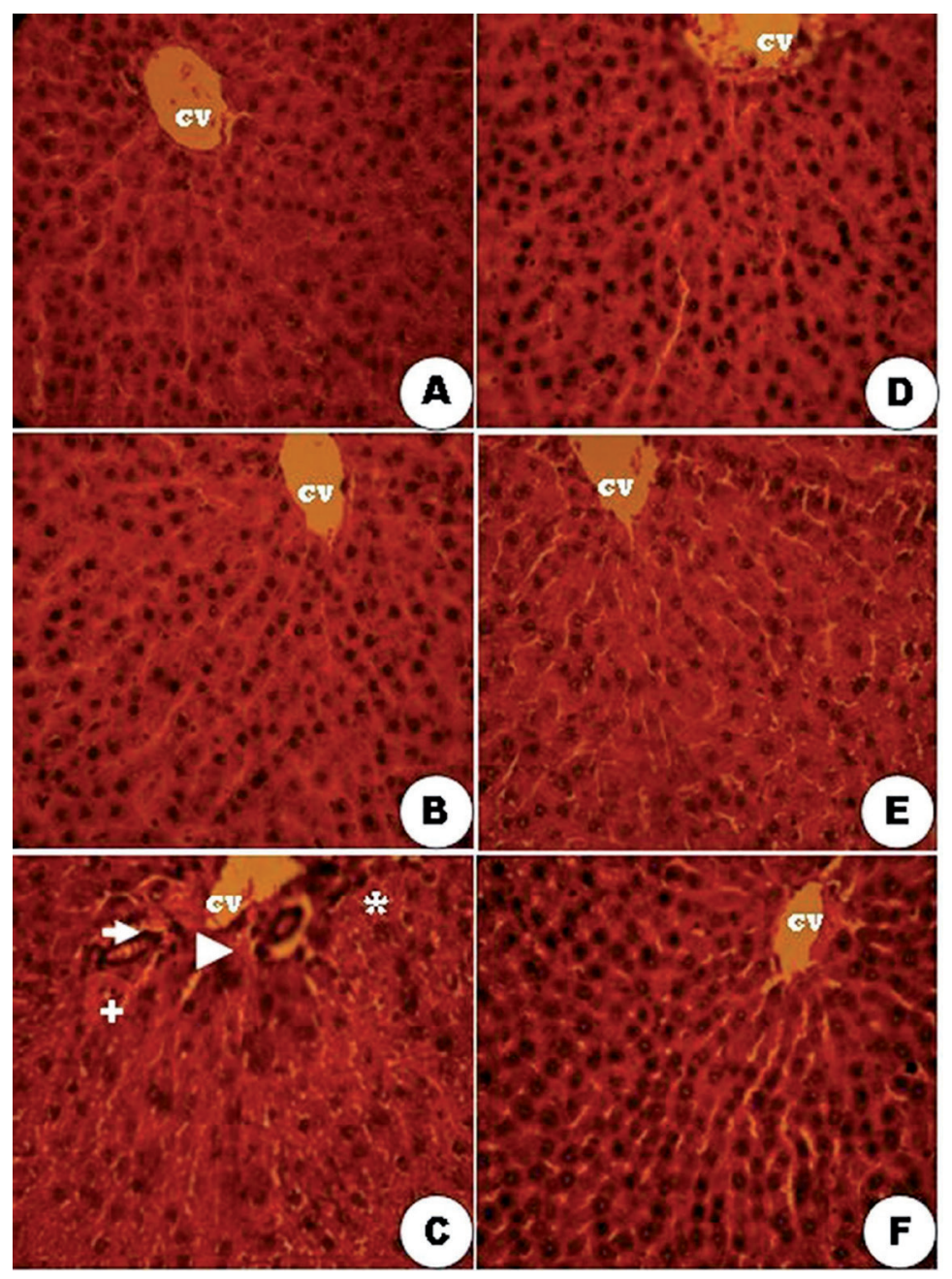

Figure 4. Histopathological observation of rat hepatic tissue stained by hematoxylin and eosin (H\&E): control liver showing normal architecture (A), liver from treated groups that received $A$. campestris essential oil (B), deltamethrin (C), A. campestris essential oil in combination with deltamethrin (D), vitamin $\mathrm{E}(\mathbf{E})$ and the combination of vitamin $\mathrm{E}$ and deltamethrin (F). Original magnifications: $\times 400$; cv, central vein in the liver; white arrow, inflammatory cell infiltration; arrow head, vascular congestion; + vacuolization; ${ }^{\star}$ lysed cells. 


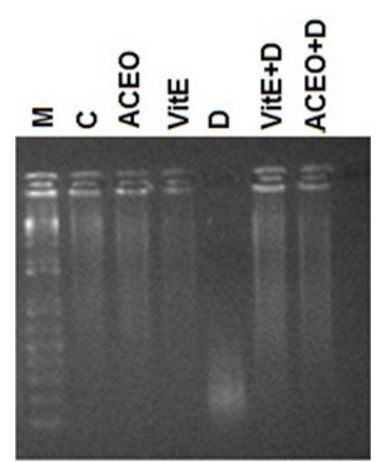

Figure 5. Effects of deltamethrin, Artemisia campestris essential oil (ACEO), vitamin $\mathrm{E}$ and their combination $(\mathrm{ACEO}+\mathrm{D}$ and $\mathrm{VitE}+\mathrm{D})$ on genomic DNA fragmentation of rat liver of control (C) and experimental rats. M, marker (2 kb DNA ladder); C, control; ACEO, Artemisia campestris essential oil; VitE, vitamin E; D, deltamethrin; $\mathrm{VitE}+\mathrm{D}$, vitamin $\mathrm{E}+$ deltamethrin; $\mathrm{ACEO}+\mathrm{D}$, Artemisia campestris essential oil+deltamethrin.

related to the prevention of propagation of lipid peroxidation process and they seem to be good scavengers of active oxygen species, thus reducing the rate of reaction (Sahreen et al. 2010). The antioxidant activity of plant essential oil is usually linked to their phenolic content. Many studies have evaluated the relationships between the antioxidant activity of plant products and their phenolic content (Birasuren et al. 2013). It seems that polyphenolic compounds in plant essential oils scavenged and reduced free radicals (Al-Jaber et al. 2011). ACEO presented a large number of different groups of chemical compounds; it is likely that the antioxidant properties of ACEO cannot be attributable to one or the major components but the whole constituents. However, some components such as carvacrol are able to cause beneficial properties as described by Coutinho de Oliveira et al. (2012) who demonstrated that thymol and carvacrol as the major components of Satureja montana L. essential oil are able to disintegrate the outer membrane of Gram-negative bacteria. In addition, a-terpineol major components presented in essential oil of Artemisia rupestris aerial parts exhibited insecticidal effects (Liu et al. 2013). ACEO has been shown to have higher phenolic and tannins contents as compared to the extract of A. campestris (Akrout et al. 2011). The phytochemical study of ACEO by GC-MS analysis revealed that monoterpene hydrocarbons constitute the major fraction of the oil.

Our results are in accordance to the reports of Akrout et al. (2011) with some modifications. However, the substances that scavenge reactive species in vitro cannot necessarily act as antioxidants in vivo (Forman et al. 2014). On the other hand, compounds lacking electron donor groups (e.g. aldehydes such as cinnamaldehyde) can act as antioxidants in vivo. In this regard, the paradoxical oxidative activation of antioxidant signalling pathways maintaining protective oxidoreductases and their nucleophilic substrates was suggested as a major mechanism action for polyphenolic antioxidants in vivo.

The in vivo study revealed that deltamethrin administration increased significantly AST, ALT and ALP activities in serum of treated rats as compared to controls. The increase in serum AST, ALT and ALP is in agreement with the findings of Yousef et al. (2006). These enzymes increased significantly indicating liver damage and thus cause alteration in liver function (Giannini et al. 2005). In this case, deltamethrin caused cellular damage which is eventually accompanied by increasing cell membrane permeability (Amin and Hashem 2012). These results clearly indicated that deltamethrin have stressful effects on the hepatic tissues consistent with those reported in the literature (Abdel-Daim et al. 2013).

Plants are considered as unique sources of useful metabolites. The increasing attention on plants used as a source of bionutrients or bio-active phytochemical have been regarded as possible antioxidants in food industry and in the chemoprevention of diseases resulting from oxidative stress (Sharoba et al. 2015). In the current study, ACEO normalized the disturbance of serum biochemical parameters (AST, ALT and ALP) in rats treated by deltamethrin. In addition, the co-treatment of rats by vitamin $\mathrm{E}$, used as standard antioxidant molecule, in combination with deltamethrin returned significantly the hepatic enzyme markers to normal values as compared to controls and deltamethrin alone. Deltamethrin exposure produced an accumulation of oxidative damage confirmed by an increase in lipid peroxidation levels (LPO) in hepatic tissue. Conjugated dienes and MDA have been extensively used as markers of oxidative stress indicating membrane damage due to LPO (Slaninova et al. 2009). The increase in the concentration of MDA (measured as TBARS) and conjugated dienes is an indicator of deltamethrininduced LPO leading to tissue injury. Although pesticides were shown to interact with membranes directly (thus altering their fluidity), it is probably not the interaction of deltamethrin with membranes that causes LPO, but rather ROS generated during deltamethrin metabolism that cause membrane lipids oxidation contributing to membrane disintegration and fluidity changes. Regardless, mitochondrial membrane fluidity alterations could indeed contribute to ROS generation (Singh et al. 2010). However, antioxidant enzymes are considered to be the first line of cellular defense against oxidative damage. Among them, SOD and CAT are responsible for the elimination of reactive oxygen species. In the present study, deltamethrin treatment induced a significant decrease of antioxidant enzymes such as SOD, CAT and GPx activities as compared to controls. The disturbance in biologic antioxidant enzymes is responsible for the cytotoxic effects of deltamethrin. This decrease could be a consequence of the high production of superoxide anion following the pyrethroid treatment. The histopathological observations in deltamethrin-treated rats showed severe liver damage 
including vacuolisation, inflammatory cell infiltration and vascular congestion. Similar findings of liver damage during deltamethrin toxicity have been observed (Amin and Hashem 2012). In addition to oxidative stress, the present paper suggests that deltamethrin exposure induced liver DNA fragmentation in treated rats as compared to controls.

Several in vitro and in vivo studies have reported toxic effects of deltamethrin in a variety of cell types. ROS are involved in apoptosis as well as in cell proliferation. Kumar et al. (2016) revealed that deltamethrin induces apoptosis in murine splenocytes in a concentration-dependent manner by an increase of p38 MAP kinase and Bax (proapoptotic) expression. Our study is in accordance with previous findings which demonstrated that rats exposed to lambda cyhalothrin induced hepatic DNA fragmentation (Madkour 2012). Recently, deltamethrin exposure to rainbow trout muscles to acute and long-term administration significantly increased the expression of cytochrome P450 1A in a time-dependent manner (Erdogan et al. 2011). In addition, CYP $4501 \mathrm{~A}$ can enhance the generation of ROS, such as superoxide radical, hydroxyl radical, and hydrogen peroxide. Park et al. (1996) demonstrated that induction of CYP 1 A by 2,3,7,8-tetrachloro dibenzo-p-dioxin (TCDD) can generate sufficient levels of ROS to cause oxidative DNA damage in hepatoma cells.

ACEO, a phenolic compound, exhibits protective effects against oxidative damage and cellular toxicity as shown by Akrout et al. (2011). Rats received ACEO along with deltamethrin showed a decrease in hepatic MDA (measured as TBARS) and conjugated dienes as compared to deltamethrin alone treated rats which indicate that essential oil scavenged free radicals produced hepatic membrane damage. More importantly, it was shown in the present study that administration of ACEO reversed the hepatic oxidative damage as confirmed by suppression of its markers, MDA (measured as TBARS) and conjugated dienes in deltamethrin treatment group. These results are similar to the observation of another study where leave extract of Ocimum basilicum was shown to decrease LPO levels in deltamethrin induced nephrotoxicity damage in rats (Sakr and Al-Amoudi 2012). In addition, ACEO administration to deltamethrin treated rats significantly increased the SOD, CAT and GPx activities. It could be due to the free radical scavenging and antioxidant property of ACEO. Moreover, our results showed that ACEO supplementation ameliorates the histological alterations induced by deltamethrin suggesting the antioxidant and antiradical efficacy of ACEO. A protective effect of ACEO has also been reported in earlier studies that postulated the beneficial role of Artemisia campestris on the histopathological changes in rats (Barkat et al. 2015). Furthermore, the co-administration of ACEO moderately decreased the liver DNA fragmentation. On the other hand, this study demonstrates that vitamin E administration had the ability to reduce the hepatic oxidative damage of deltamethrin, as indicated by the significant reduction of hepatic MDA (measured as TBARS) and conjugated dienes. Our results are consistent with those of Yousef et al. (2006) who demonstrated that rats given the deltamethrin and vitamin $\mathrm{E}$ showed amelioration and protective effect on biochemical parameters, which did not differ significantly from control values in comparison with corresponding values in rats given only deltamethrin. Our results are also in line with those mentioned previously (Bansal et al. 2005) concerning the antioxidant effect of vitamin $\mathrm{E}$ on the anti/pro-oxidant status in rats exposed to $\mathrm{N}$-nitrosodiethylamine. Rats received vitamin $\mathrm{E}$ ameliorated hepatic histoarchitecture and DNA fragmentation induced by deltamethrin. Reports of Salah et al. (2010) showed that vitamin $\mathrm{E}$ is present in the membranes of cells and cellular organelles where it plays an important role in the suppression of oxidative damage. The administration of vitamin $\mathrm{E}$ in olive oil reduced the hepatic oxidative damage caused by deltamethrin in treated rats. In addition, the use of olive oil as a solvent for the vitamin $\mathrm{E}$ has also beneficial effects against toxicity induced by deltamethrin. Olive oil presents various components such as monounsaturated fatty acids that may have nutritional benefits. It is also a good source of phytochemicals, including polyphenolic compounds (Lavelli 2002).

In conclusion, data of the present study clearly suggest the antioxidant potential of ACEO which revealed a beneficial effect in combating the hepatic oxidative damage induced by deltamethrin.

Acknowledgments. This work was supported by the DGRST Grants (Physiopathologie environnementale, valorisation des molécules bioactives et modélisation mathématique UR/13/ES73), Tunisia. Special thanks go to Miss Gammoudi A (Faculty of Arts and Humanities of Sfax) for her kind help with English.

Conflicts of interest. We declare that we have no conflict of interest.

\section{References}

Abdel-Daim M. M., Abuzead S. M. M., Halawa S. M. (2013): Protective role of Spirulina platensis against acute deltamethrininduced toxicity in rats. PLoS ONE 8, 1-7 https://doi.org/10.1371/journal.pone.0072991

Abd El-Rahman Refaie A., Ramdan A., Halim Mossa A. T. (2014): Oxidative damage and nephrotoxicity induced by prallethrin in rat and the protective effect of Origanum majorana essential oil. Asian Pac. J. Trop. Med. 7, 506-513 https://doi.org/10.1016/S1995-7645(14)60282-0

Adams R. (1995): Identification of Essential oil Components by Gas Chromatography and Mass Spectroscopy. Carol Stream, Allured Publ. Corp., IL

Adams R. P. (2007): Identification of Essential Oil Components by Gas Chromatography/Mass Spectrometry. (4th ed.), Carol Stream, Allured Publ., IL

Aebi H. (1974): Catalase in vitro. Methods Enzymol. 105, 121-126 https://doi.org/10.1016/S0076-6879(84)05016-3 
Akrout A., Gonzalez L. A., El Jani H., Madrid P. C. (2011): Antioxidant and antitumor activities of Artemisia campestris and Thymelaea hirsuta from southern Tunisia. Food Chem. Toxicol. 49, 342-347 https://doi.org/10.1016/j.fct.2010.11.003

Al-Jaber A. N., Awaad A. S., Moses J. E. (2011): Review on some antioxidant plants growing in Arab world. J. Saudi Chem. Soc. 15, 293-307 https://doi.org/10.1016/j.jscs.2011.07.004

Amin K. A., Hashem K. S. (2012): Deltamethrin-induced oxidative stress and biochemical changes in tissues and blood of catfish (Clarias gariepinus): antioxidant defense and role of alphatocopherol. BMC Veter. Res. 8, 45-53 https://doi.org/10.1186/1746-6148-8-45

Bansal A. K., Bansal M., Soni G., Bhatnagar D. (2005): Protective role of Vitamin E pre-treatment on N-nitrosodiethylamine induced oxidative stress in rat liver. Chem. Biol. Interact. 156, 101-111 https://doi.org/10.1016/j.cbi.2005.08.001

Barkat L., Boumendjel A., Saoudi M., El Feki A., Messarah M. (2015): Artemisia campestris Leaf aqueous extract alleviates methidathion-induced nephrotoxicity in rats. Int. J. Pharm. Sci. Rev. Res. 32, 200-209

Beyer W. F., Fridovich I. (1987): Assaying for superoxide dismutase activity: some large consequences of minor changes in conditions. Anal. Biochem. 161, 559-566 https://doi.org/10.1016/0003-2697(87)90489-1

Birasuren B., Kim N. Y., Jeon H. L., Kim M. R. (2013): Evaluation of the antioxidant capacity and phenolic content of Agriophyllum pungens seed extracts from Mongolia. Prev. Nutr. Food Sci. 18, 188-195 https://doi.org/10.3746/pnf.2013.18.3.188

Boulanouar B., Abdelaziz G., Aazza S., Gago C., Miguel M.G. (2013): Antioxidant activities of eight Algerian plant extracts and two essential oils. Ind. Crop. Prod. 46, 85-96 https://doi.org/10.1016/j.indcrop.2013.01.020

Broadhurst R. B., Jones W. T. (1978): Analysis of condensed tannins using acidified vanillin. J. Sci. Food Agric. 29, 788-794 https://doi.org/10.1002/jsfa.2740290908

Buege J. A., Aust S. D. (1972): Microsomal lipid peroxidation. Method. Enzymol. 51, 302-310

Catinot R., Hoellinger H., Pfister A., Sonnier M., Simon M.T. (1989): Effects on rats of subacute intoxication with deltamethrin via an osmotic pump. Drug Chem. Toxicol. 12, 173-196 https://doi.org/10.3109/01480548908999153

Chung S.K., Osawa T., Kawakishi S. (1997): Hydroxyl radical scavenging effects of species and scavengers from brown mustrad (Brassica nigra). Biosci. Biotechnol. Biochem. 61, 118-123 https://doi.org/10.1271/bbb.61.118

Coutinho de Oliveira T. L., Fitano de Carvalho S. M., Soares R. A., Andrade M. A., Graças Cardoso M., Ramos E. M., Piccoli R. H. (2012) : Antioxidant effects of Satureja montana L. essential oil on TBARS and color of mortadella-type sausages formulated with different levels of sodium nitrite. LWT - Food Sci. Technol. 45, 204-212 https://doi.org/10.1016/j.lwt.2011.09.006

Erdogan O., Ceyhun S. B., Ekinci D., Aksakal E. (2011): Impact of deltamethrin exposure on mRNA expression levels of metallothionein A, B and cytochrome P450 1A in rainbow trout muscles. Gene 484, 13-17 https://doi.org/10.1016/j.gene.2011.05.026

Forman H. J., Davies K. J., Ursini F. (2014): How do nutritional antioxidants really work: nucleophilic tone and para-hormesis versus free radical scavenging in vivo. Free Radic. Biol. Med. 66, 24-35 https://doi.org/10.1016/j.freeradbiomed.2013.05.045

Flohé L., Günzler W. A. (1984): Analysis of glutathione peroxidase. Methods Enzymol. 105, 114-121 https://doi.org/10.1016/S0076-6879(84)05015-1

Gabe M. (1968): Techniques Histologiques (Histological technics). Masson Publisher, Paris.

Galal M. K., Khalaf A. A. A., Ogaly H. A., Ibrahim M. A. (2014): Vitamin $\mathrm{E}$ attenuates neurotoxicity induced by deltamethrin in rats. Comp. Altern. Med. 14, 458-465 https://doi.org/10.1186/1472-6882-14-458

Gomez E., Ledbetter C. A. (1994): Comparative study of the aromatic profiles of two different plum species: Prunus salicina Lindl and Prunus simonii L. J. Sci. Food Agric. 65, 111-115 https://doi.org/10.1002/jsfa.2740650116

Giannini E. G., Testa R., Savarino V. (2005): Liver enzyme alteration: a guide for clinicians. Can. Med. Assoc. J. 172, 367-379 https://doi.org/10.1503/cmaj.1040752

Gündüz E., Ülger B. V., İbiloğlu I., Ekinci A., Dursun R., Zengin Y., İçer M., Uslukaya O., Ekinci C., Güloğlu C. (2015): Glutamine provides effective protection against Deltamethrin-induced acute hepatotoxicity in rats but not against nephrotoxicity. Med. Sci. Monit. 21, 1107-1114 https://doi.org/10.12659/MSM.893180

Kasangana P. B., Haddad P. S., Stevanovic T. (2015): Study of polyphenol content and antioxidant capacity of Myrianthus Arboreus (Cecropiaceae) root bark extracts. Antioxidants 4, 410-426 https://doi.org/10.3390/antiox4020410

Kirby A. J., Schmidt R. J. (1997): The antioxidant activity of Chinese herbs for eczema and of placebo herbs. J. Ethnopharmacol. 56, 103-108 https://doi.org/10.1016/S0378-8741(97)01510-9

Kumar A., Sasmal D., Bhaskar A., Mukhopadhyay K., Thakur A., Sharma N. (2016): Deltamethrin-induced oxidative stress and mitochondrial caspase-dependent signaling pathways in murine splenocytes. Environ. Toxicol. 31, 808-819 https://doi.org/10.1002/tox.22091

Lavelli V. (2002): Comparison of the antioxidant activities of extra virgin olive oils. J. Agric. Food Chem. 50, 7704-7708 https://doi.org/10.1021/jf020749o

Liu X. C., Li Y. P., Li H. Q., Deng Z. W., Zhou L., Liu Z. L., Du S. S. (2013): Identification of repellent and insecticidal constituents of the essential oil of Artemisia rupestris L. aerial parts against Liposcelis bostrychophila Badonnel. Molecules 18, 10733-10746 https://doi.org/10.3390/molecules180910733

Lowry O. H., Rosebrough N. J., Farr A. L., Randall R. J. (1951): Protein measurement with Folin phenol reagent. J. Biol. Chem. 193, 265-275

Madkour N. K. (2012): Protective effect of curcumin on oxidative stress and DNA fragmentation against lambda cyhalothrininduced liver damage in rats. J. Appl. Pharm. Sci. 2, 76-81

Magendira Mania V., Ashab S., Mohamed Sadiq A. M. (2014): Pyrethroid deltamethrin-induced developmental neurodegenerative cerebral injury and ameliorating effect of dietary glycoside naringin in male wistar rats. Biomed. Aging Pathol. 4, 1-8 
https://doi.org/10.1016/j.biomag.2013.11.001

Marongiu B., Porcedda S., Piras A., Sanna G., Murreddu M., Loddo R. (2006): Extraction of Juniperus communis L. ssp. nana Willd essential oil by supercritical carbon dioxide. Flavour Fragr. J. 21, 148-154 https://doi.org/10.1002/ff.1549

Mazmanci B., Mazmanci M. A., Unyayar A., Unyayar S., Cekic F. O., Deger A. G., Yalin S., Comelekoglu U. (2011): Protective effect of Funalia trogii crude extract on deltamethrin-induced oxidative stress in rats. Food Chem. 125, 1037-1040 https://doi.org/10.1016/j.foodchem.2010.10.014

Miller S. A., Dykes D. D., Polesky H. F. (1988): A simple salting out procedure for extracting DNA from human nucleated cells. Nucleic Acids Res. 16, 12-15 https://doi.org/10.1093/nar/16.3.1215

Morais L. A. S. (2009): Influência dos fatores abióticos nacomposição química dos óleos essenciais. Horticultura Brasileira 27, 4050-4063 (in Spanish)

Nieradko-Iwanicka B., Borzecki A. (2015): Subacute poisoning of mice with deltamethrin produces memory impairment, reduced locomotor activity, liver damage and changes in blood morphology in the mechanism of oxidative stress. Pharmacol. Rep. 67, 535-541 https://doi.org/10.1016/j.pharep.2014.12.012

Okoh S. O., Asekun O. T., Familoni O. B., Afolayan A. J. (2014) Antioxidant and free radical scavenging capacity of seed and shell essential oils extracted from Abrus precatorius (L). Antioxidants 3, 278-287 https://doi.org/10.3390/antiox3020278

Oyaizu M. (1986): Studies on products of browning reactions: antioxidative activities of browning reaction prepared from glucosamine. Jpn. J. Nutr. 44, 307-315 https://doi.org/10.5264/eiyogakuzashi.44.307

Park J. K., Schigenaga M. K., Ames B. N. (1996): Induction of cytochrome P450 1A by 2, 3, 7, 8-tetrachlorodibenzo-p-dioxin or indolo $(3,2-b)$ carbazole is associated with oxidative DNA damage. Proc. Natl. Acad. Sci. U.S.A. 93, 2322-2327 https://doi.org/10.1073/pnas.93.6.2322

Radulovic N. S., Randjelovic P. J., Stojanovic N. M., Blagojevic P. D., Stojanovic-Radic Z. Z., Ilic I. R., Djordjevic V. B. (2013): Toxic essential oils. Part II: Chemical, toxicological, pharmacological and microbiological profiles of Artemisia annua L. volatiles. Food Chem. Toxicol. 58, 37-49 https://doi.org/10.1016/j.fct.2013.04.016

Rehman H., Ali M., Atif F., Kaur M., Bhatia K., Raisuddin S. (2006): The modulatory effect of deltamethrin on antioxidants in mice. Clin. Chim. Acta 369, 61-65 https://doi.org/10.1016/j.cca.2006.01.010

Ruther J. (2000): Retention index database for identification of general green leaf volatiles in plants by coupled capillary gas chromatography-mass spectrometry. J. Chromatogr. A. 890, 313-319 https://doi.org/10.1016/s0021-9673(00)00618-x

Sahreen S., Khan M. R., Khan R. A. (2010): Evaluation of antioxidant activities of various solvent extracts of Carissa opaca fruits. Food Chem. 122, 1205-1211 https://doi.org/10.1016/j.foodchem.2010.03.120

Sakr S. A., Al-Amoudi W. M. (2012): Effect of leave extract of Ocimum basilicum on deltamethrin induced nephrotoxicity and oxidative stress in albino rats. J. Appl. Pharm. Sci. 2, 22-27
https://doi.org/10.7324/JAPS.2012.2507

Salah S. H., Abdou H. S., Abdel Rahim E. A. (2010): Modulatory effect of vitamins A, C and E mixtures against tefluthrin pesticide genotoxicity in rats. Pest. Biochem. Physiol. 98, 191-197 https://doi.org/10.1016/j.pestbp.2010.06.006

Saoudi M., Messarah M., Boumendjel A., Jamoussi K., Abdelfattah F. (2011): The protective effects of vitamin C against haematological and biochemical toxicity induced by deltamethrin in male Wistar rats. Ecotox. Environ. Safe 74, 1765-1769 https://doi.org/10.1016/j.ecoenv.2011.04.003

Senthil Kumar R., Rajkapoor B., Perumal P. (2012): Antioxidant activities of Indigofera cassioides Rottl. Ex. DC using various in vitro assay models. Asian Pac. J. Trop. Biomed. 2, 256-261 https://doi.org/10.1016/S2221-1691(12)60019-7

Seren G., Gürgen E., Erdogan D., Elmas G., Kaplanoglu G. T., Öze G. (2013): Chemoprotective effect of ascorbic acid, $\alpha$-tocopherol, and selenium on cyclophosphamide-induced toxicity in the rat ovarium. Nutrition $29,777-784$ https://doi.org/10.1016/j.nut.2012.11.004

Sharoba A. M., El Mansy H. A., El Tanahy H. H., El Waseif K. H., Ibrahim M. A. (2015): Chemical composition, antioxidant and antimicrobial properties of the essential oils and extracts of some aromatic plants. Middle East J. Appl. Sci. 5, 344-352

Shivanoor S. M., David M. (2014): Protective role of turmeric against deltamethrin induced renaloxidative damage in rats. Biomed. Prevent. Nutr. 4, 543-553 https://doi.org/10.1016/j.bionut.2014.08.007

Singh M., Sandhir R., Kiran R. (2010): Alterations in Ca2+ homeostasis in rat erythrocytes with atrazine treatment: positive modulation by vitamin E. Mol. Cell. Biochem. 340, 231-238 https://doi.org/10.1007/s11010-010-0422-9

Slaninova A., Smutna M., Modra H., Svobodova Z. (2009): A review: Oxidative stress in fish induced by Pesticides. Neuroendocrinol. Lett. 30, 2-12

Slater T. I. (1984): Overview of methods used for detecting lipid peroxidation. Methods Enzymol. 105, 283-293 https://doi.org/10.1016/S0076-6879(84)05036-9

Wolfe K., Wu X., Liu R. H. (2003): Antioxidant activity of apple peals. J. Agric. Food Chem. 51, 609-614 https://doi.org/10.1021/jf020782a

Yagi A., Kabash A., Okamura N., Haraguchi H., Moustafa S. M., Khalifa T. I. (2002): Antioxidant, free radical scavenging and antiinflammatory effects of aloesin derivatives in Aloe vera. Planta Med. 68, 957-960

https://doi.org/10.1055/s-2002-35666

Yousef M. I., Awad T. I., Mohamed E. H. (2006): Deltamethrininduced oxidative damage and biochemical alterations in rat and its attenuation by Vitamin E. Toxicology 227, 240-247 https://doi.org/10.1016/j.tox.2006.08.008

Zoghbi M. G. B., Andrade E. H. A., da Silva M. H. L., Maia J. G. S. (2002): Volatile constituents of Lippia lupulina Cham. Flavour Fragr. J. 17, 29-31 https://doi.org/10.1002/ffj.1032

Received: June 18, 2016

Final version accepted: December 19, 2016 